\section{Cytogenetic characterization of Angelonia integerrima Sprengel, a native species with ornamental potential}

\section{Marília Tedesco ${ }^{1}$, Aquélis Armiliato Emer ${ }^{1}$, Mara Cíntia Winhelmann ${ }^{1}$, Eduarda Demari Avrella ${ }^{1}$, Karine Cristina Krycki ${ }^{2}$, Carine Simioni ${ }^{{ }^{*}}$ and Gilmar Schafer ${ }^{1}$}

\begin{abstract}
Angelonia integerrima Sprengel is a native species of the state of Mato Grosso do Sul and the Southern region (Paraná, Santa Catarina and Rio Grande do Sul) of Brazil, with features such as an unusual appearance and color of the flowers, indicating an ornamental use. To optimize the use of this species and to fill in gaps regarding its cytogenetic characterization, this study determined the chromosome number, meiotic index and pollen viability of plant individuals of four $A$. integerrima populations. All plant individuals of the four populations had $2 n=20$ chromosomes. Still, the meiotic index of most analyzed plant individuals exceeded $90 \%$, while pollen viability of all plant individuals was higher than $80 \%$. These data suggest considerable cytological stability of the analyzed A. integerrima plant individuals, which may favor the selection of future genotypes for commercial purposes or their use in conservation and breeding programs of the species.
\end{abstract}

Keywords: Caracol-do-campo, chromosome number, meiotic index, pollen viability, plant genetic resources.

\section{INTRODUCTION}

Angelonia integerrima Sprengel, popularly known as Angelonia, caracol-docampo or violeta-do-campo in Brazil, is a native species that occurs in stony fields and rocky outcrops in Mato Grosso do Sul and the Southern Region (Paraná, Santa Catarina and Rio Grande do Sul) of Brazil, and close to the Brazilian borders of Paraguay and Argentina (Souza and Giulietti 2009).

This species has a considerable ornamental potential in view of features such as herbaceous growth, the contrast caused by the color difference between stem and leaves, inflorescences with flowers at different maturation stages (increasing the duration of flowering), aside from the peculiar aspect of the flowers. It can be cultivated in flowerbeds, forming clumps, as well as in rock gardens, flower planters and even pots (Stumpf et al. 2009).

Although the Brazilian flora presents a great biodiversity, including species with ornamental characteristics such as $A$. integerrima, the number of native species cultivated commercially is still derisory (Heiden et al. 2006). However, a reduction or even replacement of exotic ornamental species by native ones is a trend that has been consolidating in the modern landscaping (Heiden et
Crop Breeding and Applied Biotechnology

19: 118-125, 2019 Brazilian Society of Plant Breeding. Printed in Brazil http://dx.doi.org/10.1590/198470332019v19n1a16

\footnotetext{
*Corresponding author: E-mail: carine.simioni@ufrgs.br (iD) ORCID: 0000-0002-0642-6980
}

Received: 15 March 2018 Accepted: 15 April 2018

${ }^{1}$ Universidade Federal do Rio Grande do Sul, Departamento de Horticultura e Silvicultura, 91.501-970, Porto Alegre, RS, Brazil

2 Universidade Federal do Rio Grande do Sul, Departamento de Plantas Forrageiras e Agrometeorologia, 91.501-970, Porto Alegre, RS, Brazil 
al. 2007), emerging as a new niche in the floriculture market, with great potential of production and commercialization (Oliveira Junior et al. 2013).

However, to introduce $A$. integerrima into cultivation, some aspects must be known. Among these, the cytogenetic characterization is essential, for providing a foundation for related studies that contribute both to the use of native material with economic potential and to the preservation of the species germplasm (Valls 2007). Moreover, the information generated may provide a basis underlying breeding, with a view to developing the commercially most promising material (Cruz et al. 1993).

The knowledge about the chromosome number of a species provides data that contribute to phylogeny and taxonomy, as well as helping to determine the most appropriate procedures to obtain hybrids in breeding programs (Heslop-Harrison 2000, Auler et al. 2006). While the analysis of the meiotic index and pollen viability allow obtaining information on genetic variability, sterility problems and possibilities of crosses (Souza et al. 2004).

The cytogenetic characterization of the genus Angelonia is doubtful, since only chromosome numbers are reported for some species such as A. grandiflora C. Morr. (Raghavan and Srinivasan 1940), A. salicariaefolia Humb. \& Bonpl. (Chandran and Bhavanandan 1983), A. cubensis (var alba) (Subramanian and Pondmudi 1987), A. gardneri Hook. (Molero et al. 2006) and Angelonia spp. (hybrid) (Plaschil and Olbricht 2008). In these studies, the chromosome number of the species was $n=10$ or $2 n=20$, suggesting that $x=5$ or $x=10$ is the basic chromosome number of the genus. Only one study in the literature determined the chromosome number of $A$. integerrima, based on a single Paraguayan population, as $2 n=20$ chromosomes (Molero et al. 2006).

Thus, to deepen the knowledge about the basic aspects of the species $A$. integerrima, which could contribute to enhance conservation strategies and underlie future breeding studies, this study addressed the description of the species in terms of chromosome number, meiotic index and pollen viability of different populations of the state of Rio Grande do Sul (RS), Brazil.

\section{MATERIAL AND METHODS}

The analyses were carried out at the Laboratory of Cytogenetics of the Department of Forage Plants and Agrometeorology (DPFA) and the Laboratory of Biotechnology of the Department of Horticulture and Forestry (DHS), at the Faculty of Agronomy of the Federal University of Rio Grande do Sul (UFRGS) in Porto Alegre, RS, Brazil.

\section{Plant material}

The plant material used included flower buds and seeds of four natural populations, resulting in a total of 44 plant individuals collected in 2016 and 2017, in localities of the state of Rio Grande do Sul (RS).

The populations with the respective geographic coordinates are listed below: Morro do Osso (MO), Porto Alegre, RS (lat 30 07' 77" S, long 51ㅇ 14' 87" W, alt 143 m asl); Morro Santana (MS), Porto Alegre, RS (lat 30 02' 14" S, long 51ㅇ 06' 33" W, alt $311 \mathrm{~m}$ asl); Barão do Triunfo (BT), Barão do Triunfo, RS (lat 30 21’ 36" S, long 51 43’ 55” W, alt 401 $\mathrm{m}$ asl) and Parque Saint'Hilaire (PSH), Viamão, RS (lat 30 5' 42.72" S, long 51 5' 9.36" W, alt $114 \mathrm{~m}$ asl). The regional climate is Cfa, i.e., humid subtropical (Pessoa 2017). The sites where the species was found were composed of native grassland areas characteristic of the Pampa biome.

\section{Chromosome number}

To determine the chromosome number, seeds of 29 Angelonia integerrima plant individuals, previously refrigerated (4 to $6 \circ \mathrm{O}$ ), were sterilized in $70 \%$ alcohol and $1 \%$ sodium hypochlorite followed by triple washing with distilled and autoclaved water. Thereafter, they were placed to germinate in Petri dishes double-lined with $\mathrm{pH}$-neutral filter $\left(\right.$ Germitest ${ }^{\circledast}$ ) paper moistened with distilled and autoclaved water. Then, the dishes were placed in a growth chamber, at a mean temperature of $25^{\circ} \mathrm{C} \pm 2$ and photoperiod of $16 \mathrm{~h}$ light. When the radicles reached an approximate length of $0.5 \mathrm{~cm}$ (seven days after sowing), they were pre-treated with $0.002 \mathrm{M} 8$-hydroxyquinoline for $23 \mathrm{~h} 30 \mathrm{~min}$ at $4 \stackrel{\circ}{\circ} \mathrm{C}$ in a refrigerator. To determine the adequate pretreatment, preliminary tests were performed. After this step, the roots were fixed in Carnoy 3:1 (absolute ethanol/glacial acetic acid $\mathrm{v} / \mathrm{v}$ ) for a period of $24 \mathrm{~h}$ at room temperature and stored 


\section{Tedesco et al.}

in $70 \%$ ethanol under refrigeration until further analysis. To analyze the mitotic metaphases, the radicles were washed in distilled water, hydrolyzed in $1 \mathrm{~N}$ hydrochloric acid at $60^{\circ} \mathrm{C}$ in a water bath for $10 \mathrm{~min}$ and rinsed again in distilled water. Thereafter, the rootlets were stained with Feulgen for about $12 \mathrm{~h}$. For the slides, root tips (meristematic region) were ground in $2 \%$ propionic carmine, covered with coverslips and sealed with nail polish.

For each plant individual, 10 - 20 cells were analyzed in mitotic metaphases, with good chromosome distribution and degree of contraction. The analyses were performed with a ZEISS microscope, coupled with an AxioCam ERc5s camera. The best metaphases were photographed and the images edited in the Adobe Photoshop program.

\section{Meiotic index and pollen viability}

Due to the development stage of the bud at collection, only the pollen grain viability could be analyzed in some plant individuals (44 plants), while in others (19) the final microsporogenesis products were also analyzed.

After collection, the flower buds at different development stages were immediately fixed in Carnoy 3:1 (absolute ethanol/glacial acetic acid v/v) for $24 \mathrm{~h}$ at room temperature. Subsequently, they were transferred to $70 \%$ ethanol and refrigerated until use. For the slides, the floral buds were dissected and the anthers removed, stained with $2 \%$ propionic carmine and crushed with a glass stick, by the methodology of Guerra and Souza (2002).

To determine the meiotic index, a mean of 310 tetrads per plant individual were analyzed. Tetrads with four cells (quartet) were considered normal, while the abnormal had other numbers (two, three or more). The meiotic index (MI) was calculated by the formula: $\mathrm{MI}=$ [number of normal tetrads/total number of tetrads (dyads, triads, tetrads, polyads] observed] x 100 (Love 1949).

To estimate the pollen viability, more mature flower buds were used, and the slides were also prepared by the methodology of anther squashing. Two dyes were used for pollen grain staining: $2 \%$ propionic carmine and Alexander staining. When using $2 \%$ propionic carmine dye, the fully stained pollen grains were considered viable and the unstained or weakly stained unviable. When using Alexander staining, purple pollen grains were considered viable and blue-green grains unviable, and the slides were analyzed $24 \mathrm{~h}$ after preparation for a better reaction of the dye. Two slides per plant individual and dye were prepared, resulting in a total of 2000 pollen grains per plant individual (500 per slide). Pollen viability was estimated by the percentage of viable grains, dividing the number of grains considered viable by the total number of grains multiplied by 100 .

For each population, the longitudinal and transverse axes of 10 plant individuals ( 10 grains per plant individual) were measured, except for the populations of Barão do Triunfo and Parque Saint-Hilaire, in which the pollen grains of three plant individuals (all plant individuals of both populations) were measured. The measurements were performed with an ocular micrometer coupled to an optical microscope.

Meiosis and pollen viability were also analyzed under a ZEISS microscope, coupled with an AxioCam ERc5s camera, and the photomicrographs edited, using Adobe Photoshop.

\section{Statistical analysis}

Data were analyzed by descriptive statistics (mean and standard deviation). For pollen viability means between populations, plant individuals and dyes, the data did not meet the assumptions of analysis of variance, even after transformations, and were therefore subjected to non-parametric analysis by the Kruskal-Wallis test, followed by means comparison by Dunn's test, using software SigmaPlot 11.0.

\section{RESULTS AND DISCUSSION}

\section{Chromosome number}

This is the first study to determine the somatic chromosome number of a large number of plant individuals of four Angelonia integerrima populations (Figure 1a). A chromosomal number of $2 n=20$ was found for all plant individuals of the four populations (Table 1). This result agrees with reports of Molero et al. (2006) for a population of $A$. integerrima in Paraguay. However, it is emphasized that the photomicrographs of the chromosomes of the species presented in this 
Table 1. Populations of Angelonia integerrima Spreng., number of plants and cells analyzed and respective chromosome number.

\begin{tabular}{lcc}
\hline $\begin{array}{l}\text { Population } \\
\text { (acronym) }\end{array}$ & $\begin{array}{c}\text { Number of plant individuals } \\
\text { (number of cells analyzed) }\end{array}$ & Chromosome number (2n) \\
\hline Morro do Osso (MO) & $12(160)$ & $2 \mathrm{n}=20$ \\
Morro Santana (MS) & $13(130)$ & $2 \mathrm{n}=20$ \\
Barão do Triunfo (BT) & $01(20)$ & $2 \mathrm{n}=20$ \\
Parque Saint'Hilaire (PSH) & $03(40)$ & $2 \mathrm{n}=20$ \\
\hline
\end{tabular}

study are new and unpublished (Figures $1 \mathrm{~b}, 1 \mathrm{c}$ and $1 \mathrm{~d}$ ). As the number of chromosomes found in the four analyzed $A$. integerrima populations is the same $(2 n=20)$, analogous to that of the Paraguayan population (Molero et al. 2006), it is assumed that there is probably no intraspecific variability.

Studies with other Angelonia species indicate that there is no intrageneric variation affecting the chromosome number either, at least with regard to the cultivated species: A. grandiflora C. Morr. (Raghavan and Srinivasan 1940), A. salicariaefolia Humb. \& Bonpl. (Chandran and Bhavanandan 1983), A. cubensis (var alba) (Subramanian and Pondmudi 1987), A. gardneri Hook. (Molero et al. 2006), and Angelonia spp. (Hybrid) (Plaschil and Olbricht 2008). In these studies, the species had $\mathrm{n}=10$ or $2 \mathrm{n}=20$ chromosomes, suggesting that $\mathrm{x}=5$ or $\mathrm{x}=10$ is the basic chromosome number of the genus.

With regard to the small sample size of the population of Barão do Triunfo (one plant individual with seeds), it is emphasized that this population is known to have comprised several A. integerrima plant individuals a few years ago, however, with the intensive conversion of native field areas into pastures and monocultures, the population was drastically reduced. Thus, this study reinforces the importance of describing this species, as a contribution to the conservation of the still existing germplasm.

Due to the small chromosome size of $A$. integerrima $(<2 \mu \mathrm{m})$, as also reported for other species of the genus (Raghavan and Srinivasan 1940), the centromere could not be accurately identified, nor the arm length measured for karyotype assembly.

According to Guerra (1990), the analysis of several populations of a same species can provide information about the cytological stability of the species, as observed in A. integerrima, and on the existence of intraspecific variability or even subspecies. It is worth remembering that the chromosome number of a species must be determined in several plant individuals and populations, and voucher specimen of the analyzed material should be deposited in a herbarium, underlying the identification of the species under study (Castro et al. 2006).

\section{Meiotic index and pollen viability}

Data resulting from the analysis of microsporogenesis end products indicated a high percentage of normal tetrads, with meiotic index average of $92.9 \%$ (Table 2). In this study, some irregularities such as dyads, triads and polyads (Figure $2 \mathrm{a}, 2 \mathrm{~b}$, and $2 \mathrm{c}$ ) were observed, although the number of normal tetrads ( $2 \mathrm{~d}$ ) was the highest.

There are no literature reports on the chromosome behavior at the end of meiosis and/or on the pollen viability of $A$. integerrima. For the genus Angelonia, Molero et al.
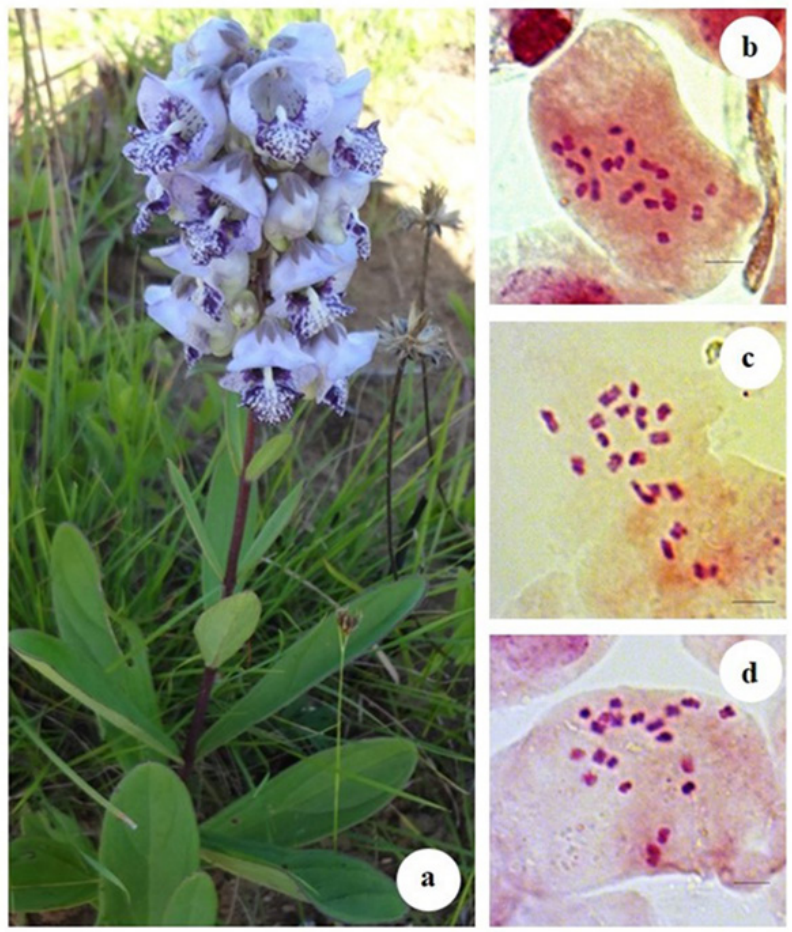

Figure 1. (a) General aspect of Angelonia integerrima Spreng. in natural environment (Parque Saint-Hilaire); $(b-d)$ : Mitotic metaphases with $2 n=20$ chromosomes of the populations from Morro do Osso, Morro Santana and Parque Saint-Hilaire, respectively. 


\section{Tedesco et al.}

(2006) studied the meiotic behavior of $A$. gardneri, identifying normal chromosome segregation, with few irregularities. Ten bivalents $(n=10)$ in diacinesis/metaphase I were found.

A single plant individual presented had a low meiotic index (64.15\% - data not shown), indicating that a series of irregularities may have occurred during meiosis, resulting in gamete imbalance. The same plant individual also had the lowest percentage of pollen viability ( $82.3 \%$ - data not shown). As pollen viability is directly related to gamete formation during meiosis (Diegues et al. 2015), it is expected that a plant with a low meiotic index will also have a lower pollen grain viability.

In addition, in relation to the meiotic index, the values of the other individuals analyzed were on average greater than 90\%. (Table 2). According to Love (1949), plants with a meiotic index of more than $90 \%$ are considered to be cytologically stable and can therefore be included in breeding programs and used for species preservation.

Despite the simplicity of the parameter, the meiotic index is a commonly used indicator of regularity in studies on the meiotic behavior of plants (Love 1949). Consequently, this index is also widely used to identify the best genotypes for inclusion in breeding and conservation programs, particularly with regard to native species, which have been increasingly addressed by specific studies in the last two decades.

The high meiotic indices found here, indicating the regularity in the meiotic behavior of $A$. integerrima, corroborate the statement of Füller et al. (2015) that high-frequency meiotic irregularities in natural populations are not a common phenomenon. This was also observed in studies with natural populations of Elionurus muticus (Spreng.) Kuntze (Füller et al. 2015), Bidens pilosa L. (Fachinetto et al. 2008), Baccharis trimera (Less.) DC. (Auler et al. 2006), and Eugenia involucrata DC. (Guerra et al. 2016), which are also native species of the South-Brazilian flora.

Pollen viability was analyzed in 44 plant individuals of four $A$. integerrima populations. The mean value of pollen viability was used as the carmine propionic dye was of 96.1 and with the alexander staining was of 96.5 (Table 2). The statistical analysis showed no significant difference when comparing pollen viability between populations and between dyes ( $p$-value for populations: 0.644; $p$-value for dyes: 0.378 ). However, a significant difference ( $p$-value: $<0.001$ ) was observed among individuals within the populations, which indicates that the species may present a reasonable genetic variability for the characteristic pollen viability under the conditions of this study. This difference can also be explained by environmental factors such as temperature, humidity and pollen stage (Kelly et al. 2002), since the samplings were carried out on days with different climatic conditions.

Information on pollen viability and morphology are scarce for both the genus Angelonia and the family Plantaginaceae. Thus, our results constitute important information for the characterization of this taxon. The pollen grains of $A$. integerrima are predominantly rounded, with a mean polar axis $(P)$ length between 18.33 and $20.86 \mu \mathrm{m}$ and equatorial axis (E) between 18.67 and $20.86 \mu \mathrm{m}$. Compared to the pollen grains of other herbaceous species, such as Sisyrinchium micranthum Cav. (Tacuatiá et al. 2012), with an equatorial axis length of grains between 29.71 and $36.35 \mu \mathrm{m}$ and polar axis between 25.19 and $30.34 \mu \mathrm{m}$, the $A$. integerrima pollen grains are considered small.

The pollen viability was tested with two dyes, propionic carmine and Alexander staining, since some authors claimed that their efficiency is different, for staining the pollen grains differently (Auler et al. 2006, Coelho et al. 2012, Hister and Tedesco 2016). While propionic carmine reddens viable grains and leaves unviable grains unstained (Figure 2e),

Table 2. Final meiotic products, meiotic index (\%) and mean of pollen viability of four populations of Angelonia integerrima Spreng.

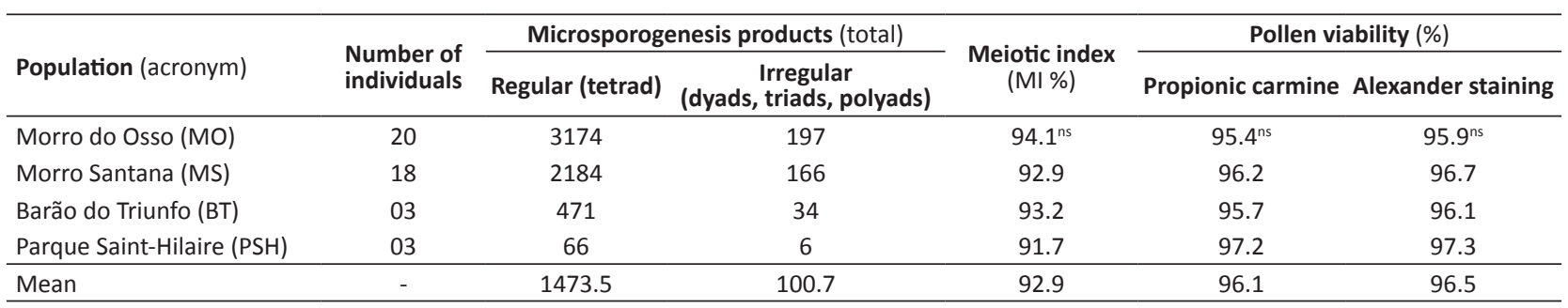

ns: no significant differences in average ( $5 \%$ probability) by Dunn's test. 

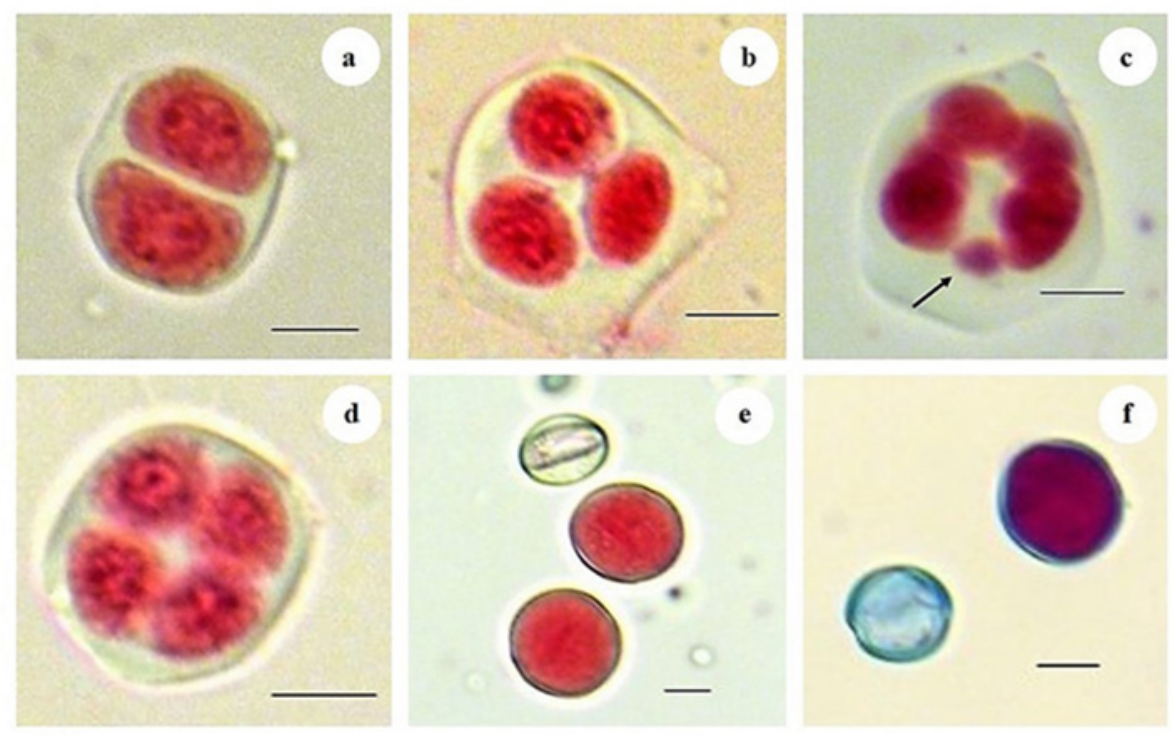

Figure 2. Pollen grains and microsporogenesis end products of Angelonia integerrima Spreng. (a) dyad; (b) triad; (c) polyad with microcyst (arrow); (d) normal tetrad; (e) pollen grains stained with propionic carmine: viable (stained red) and unviable (unstained); (f) pollen grains stained with Alexander staining: viable (stained purple) and unviable (stained blue). Scale: $10 \mu \mathrm{m}$.

the Alexander staining, which contains the dyes fuchsin and malachite green, produces a differential staining between viable and unviable pollen grains. The cellulose in the pollen cell wall reacts with malachite green to produce a bluegreen color, while the protoplasm reacts with acid fuchsin to produce a purple color (Alexander 1980). Thus, as unviable grains have no protoplasm, they have a blue-green color, while viable grains have a blue-green cellulose wall and purple protoplasm (Figure 2f).

Nevertheless, the means of pollen viability, determined with propionic carmine and Alexander staining, were not significantly different in this study (Table 2), indicating that both are efficient to estimate the viability of $A$. integerrima pollen grains.

In a study with Citrus species, Moreira and Gurgel (1940) defined that pollen viability above $70 \%$ can be considered high. Based on this definition, high pollen viability was detected in all plants analyzed of both populations. Parallel to the meiotic indices found, a high percentage of viable pollen grains is expected in view of the high percentage of normal tetrads, which are a direct reflection of a regular meiotic process (Corrêa et al. 2005), as pointed out in this study. If the process of megasporogenesis also occurs regularly, the seed production of these plants will be problem-free and the viability good, recommending their use in breeding programs.

In addition, it is emphasized that several authors, such as Krycki et al. (2016), Costa et al. (2018), Fachinetto et al. (2018), Tolomeotti et al. (2018) and Silva et al. (2018), have carried out studies involving native species of economic importance, such as the present study.

\section{CONCLUSION}

The somatic chromosome number of all plant individuals of the four analyzed populations of $A$. integerrima is $2 n=20$. The meiotic index is superior to $90 \%$ in most of the analyzed plant individuals, whereas pollen viability exceeded $80 \%$ for all plant individuals. These data suggest a regular microsporogenesis process of the analyzed plant individuals. 


\section{ACKNOWLEDGMENTS}

We are grateful to the Conselho Nacional de Desenvolvimento Científico e Tecnológico (CNPq) and Fundação de Amparo à Pesquisa do Estado do Rio Grande do Sul (FAPERGS) for financial support.

\section{REFERENCES}

Alexander MP (1980) A versatile stain for pollen, fungi, yeast and bacteria. Stain Technology 55: 13-18.

Auler NMF, Battistin A and Reis MS (2006) Número de cromossomos, microsporogênese e viabilidade do pólen em populações de carqueja [Baccharis trimera (Less) DC.] do Rio Grande do Sul e Santa Catarina. Revista Brasileira de Plantas Medicinais 8: 55-63.

Castro B, Biondo E, Schifino-Wittmann MT and Miotto STS (2006) Estudos cromossômicos em espécies da subfamília Caesalpinioideae (Leguminosae) do Sul do Brasil: confirmação de contagens e detecção de variabilidade intra-específica em Senna occidentalis (L.). Revista Científica Rural 11: 130-134.

Chandran R and Bhavanandan KV (1983) IOPB chromosome numbers reports LXXIX. Taxon 32: 1-320.

Coelho APD, Morais KP, Laughinghouse IV HD, Giacomini SJ and Tedesco SB (2012) Pollen grain viability in accessions of Crotalaria juncea $\mathrm{L}$. (FABACEAE). Agrociencia 46: 481-487.

Corrêa MGS, Viegas J, Silva JB, Avila PFV, Busato GR and Lemes JS (2005) Meiose e viabilidade polínica na família Araceae. Acta Botanica Brasilica 19: 295-303.

Costa AM, Motoike SY, Corrêa TR, Silva TC, Coser SM, Resende, MDV and Teófilo RF (2018) Genetic parameters and selection of macaw palm (Acrocomia aculeata) accessions: an alternative crop for biofuels. Crop Breeding and Applied Biotechnology 18: 259-266.

Cruz ND, Boaventura YMS, Conagin CHTM, Dutilh JHA, Forni-Martins ER, Medina DM, Mendes AJT, Pierozzi NI and Pinto-Maglio CAF (1993) Citogenética vegetal: cinquenta e três anos de pesquisa da seção de citologia do Instituto Agronômico. IAC, Campinas, 60p.

Diegues IP, Junior PCD, Ribeiro NVS, Reis MVM and Abboud ACS (2015) Comportamento meiótico e viabilidade polínica na espécie Jatropha curcas L. Revista Ciências Agrárias 36: 141-150.

Fachinetto JM, Laughinghouse IV MHD, Silva ACF and Tedesco SB (2008) Variability of the chromosomal number and meiotic behavior in populations of Bidens pilosa from southern Brazil. Caryologia 61: 164-169.

Fachinetto JM, Dall'Agnol M, Schifino-Wittmann MT, Simioni C and Ávila MR (2018) New wild diploids in Paspalum notatum Flügge (Poaceae): potential accessions for use in breeding. Crop Breeding and Applied Biotechnology 18: 432-436.

Füller TN, Guerra D, Schifino-Wittmann MT, Tessele CB, Bergman II and Neto JFB (2015) Genetic and cytogenetic structure of wild lemon grass (Elionurus muticus) populations. Crop Breeding and Applied Biotechnology 15: 272-277.
Guerra MS (1990) A situação da citotaxonomia de angiospermas nos trópicos e, em particular, no Brasil. Acta Botanica Brasilica 4: 75-86.

Guerra M and Souza MJ (2002) Como observar cromossomos: um guia de técnicas em citogenética vegetal, animal e humana. FUNPEC, Ribeirão Preto, 131p.

Guerra D, Souza PVD, Schwarz SF, Schifino-Wittmann MT, Werlang CA and Veit PA (2016) Genetic and cytological diversity in cherry tree accessions (Eugenia involucrata DC) in Rio Grande do Sul. Crop Breeding and Applied Biotechnology 16: 219-225.

Heiden G, Barbieri RL and Stumpf ERT (2006) Considerações sobre o uso de plantas ornamentais nativas. Revista Brasileira de Horticultura Ornamental 12: 2-7.

Heiden G, Barbieri RL, Stumpf ERT and Grolli PR (2007) Uso de plantas arbóreas e arbustivas nativas do Rio Grande do Sul como alternativa a ornamentais exóticas. Revista Brasileira de Agroecologia 2: 851-853.

Heslop-Harrison JS (2000) RNA, genes, genomes and chromosomes: repetitive DNA sequences in plants. Chromosome Today 13: 45-57.

Hister CAL and Tedesco SB (2016) Estimativa da viabilidade polínica de araçazeiro (Psidium cattleianum Sabine) através de distintos métodos de coloração. Revista Brasileira de Plantas Medicinais 18: 135-141.

Oliveira Junior CJF, Gonçalves FS, Couto F and Matajs L (2013) Potencial das espécies nativas na produção de plantas ornamentais e paisagismo agroecológico. Revista Brasileira de Agroecologia 8: 190-200.

Kelly JK, Rasch A and Kalisz S (2002) A method to estimate pollen viability from pollen size variation. American Journal of Botany 89: 10211023.

Krycki KC, Simioni C and Dall'Agnol M (2016) Cytoembryological evaluation, meiotic behavior and pollen viability of Paspalum notatum tetraploidized plants. Crop Breeding and Applied Biotechnology 16: $282-288$.

Love EM (1949) La citologia como ayuda practica al mejoramiento de los cereales. Revista Argentina Agronomia 16: 1-13.

Molero J, Daviña JR, Honfi Al, Franco D and Rovira A (2006) Chromosome studies on plants from Paraguay II. Candollea 61: 373-392.

Moreira S and Gurgel JTA (1940) Exame e contagem de pólen. In Relatório da seção de citricultura. IAC, Campinas, p. 53-62.

Pessoa ML (Org.) (2017) Atlas FEE: Clima do Rio Grande do Sul. Available at: < http://atlas.fee.tche.br/rio-grande-do-sul/socioambiental/ clima/ >. Accessed on January 8, 2018.

Plaschil S and Olbricht K (2008) Histogenetic variation in flowers of Angelonia Humb. et Bonpl. Journal of Applied Botany and Food Quality 82: 41-46. 
Cytogenetic characterization of Angelonia integerrima Sprengel, a native species with ornamental potential

Raghavan TS and Srinivasan VK (1940) Studies in the Scrophulariaceae: The cytology of Angelonia grandiflora C. Merr. and some related genera. Cytologia 11: 37-54.

Silva DC, Blank AF, Nizio DAC, Sampaio TS, Nogueira PCL and Arrigoni-Blank MF (2018) Chemical diversity of essential oils from native populations of Eplingiella fruticosa. Crop Breeding and Applied Biotechnology 18: $205-214$.

Souza MM, Pereira TNS, Viana AP, Pereira MG and Amaral Junior AT (2004) Flower receptivity and fruit characteristics associated to time of pollination in yellow passion fruit. Scientia Horticulturae 1: 373-385.

Souza VC and Giulietti AM (2009) Levantamento das espécies de SCROPHULARIACEAE sensu lato nativas do Brasil. Pesquisas - série Botânica 60: 7-288.

Stumpf ERT, Barbieri RL and Heiden G (2009) Cores e formas no bioma pampa: plantas ornamentais nativas. Embrapa Clima Temperado,
Pelotas, $276 \mathrm{p}$.

Subramanian D and R Pondmudi (1987) Cytotaxonomical studies of south Indian Scrophulariaceae. Cytologia 52: 529-541.

Tacuatiá LO, Souza-Chies TT, Flores AM, Eggers L, Siljak-Yakovlev S and Kaltchuk-Santos E (2012) Cytogenetic and molecular characterization of morphologically variable Sisyrinchium micranthum (Iridaceae) in southern Brazil. Botanical Journal of the Linnean Society 69: 350-364.

Tolomeotti KRB, Felippi M and Donazzolo J (2018) Cytogenetic characterization of Tropaeolum pentaphyllum Lam. Crop Breeding and Applied Biotechnology 18: 65-71.

Valls JFM (2007) Caracterização de recursos genéticos vegetais. In Nass LL (ed) Recursos genéticos vegetais. Embrapa Recursos Genéticos e Biotecnologia, Brasília, p. 281-305. 